\title{
Plant active products and emerging interventions in water potabilisation: disinfection and multi-drug resistant pathogen treatment
}

\author{
Adeyemi O. Adeeyo ${ }^{1 *}$ D, Joshua N. Edokpayi ${ }^{2}$, Mercy A. Alabi ${ }^{3}$, Titus A. M. Msagati ${ }^{4}$ and John O. Odiyo ${ }^{2,5}$
}

\begin{abstract}
Background: This review aims at establishing the emerging applications of phytobiotics in water treatment and disinfection.

Results: Statistical analysis of data obtained revealed that the use of plant product in water treatment needs more research attention. A major observation is that plants possess multifaceted components and can be sustainably developed into products for water treatment. The seed (24.53\%), flower (20.75), leaf (16.98\%) and fruit (11.32\%) biomasses are preferred against bulb (3.77\%), resin (1.89\%), bark (1.89\%) and tuber (1.89\%). The observation suggests that novel applications of plant in water treatment need further exploration since vast and broader antimicrobial activities (63.63\%) is reported than water treatment application (36.37\%).

Conclusions: This review has revealed the existing knowledge gaps in exploration of plant resources for water treatment and product development. Chemical complexity of some plant extracts, lack of standardisation, slow working rate, poor water solubility, extraction and purification complexities are limitations that need to be overcome for industrial adoption of phytochemicals in water treatment. The field of phytobiotics should engage modern methodologies such as proteomics, genomics, and metabolomics to minimise challenges confronting phytobiotic standardisation. The knowledge disseminated awaits novel application for plant product development in water treatment.
\end{abstract}

Keywords: Microbial resistance, Phytochemicals, Water treatment, Standardisation

\section{Introduction}

Although plant products are available [1-3]and exhibit different mechanisms of action from conventional antimicrobials $[4,5]$, there are critical gaps in the exploration of plant resources [6] for development of useful products [7]. The variation and complexity in chemical compositions of plants potentiate their activity [5]. Different phytochemicals present in plants such as phenols, quinones, flavonols, tannins, coumarins and alkaloids are responsible for plant activities. Flavonols and phenolics

\footnotetext{
* Correspondence: firstrebby@gmail.com

'Department of Ecology and Resource Management, University of Venda,

Private Bag X5050, Thohoyandou 0950, South Africa

Full list of author information is available at the end of the article
}

have been reported for their antioxidant activity exerted by scavenging the 'free-oxygen radicals' thereby giving rise to a fairly 'stable radical. Cinnamaldehyde and other polyphenols have been known for their anti-diabetic activity by enhancing the amount of insulin-like TTP (Thrombotic Thrombocytopenic Purpura), IR (Insulin Resistance), and GLUT4 (Glucose Transporter-4) in 3 T3-L1 Adipocytes. Phenolic acids are known for their antimicrobial activity by reduction of adherence of organisms to cells and essential oils for their antiinflammatory effect by suppressing nitric oxide production $[8,9]$.

Current interventions of plants dealing with microbial resistance, immunomodulation, as antitumour agents, 
maintenance of illnesses affecting immune systems and in microbial virulence attenuation have been described in various researches [10-13]. In the early days of use, plants were used in their crude state [14] and contribute greatly to the health care system of local communities [15]. Ethnomedicinally, plants have found application in the treatment of several diseases and ailments. Examples are Astragalus membranaceus, roots of Trichosanthes kirilowii, roots and rhizomes of Panax quinoquefolusin and pulps of Cornus officinalis reported for treatment of diabetes mellitus.

Terminalia chebulaand Adenocarpus mannii are known for their immunomodulation properties [16, 17], Thea assamica in the treatment of impetigo [18], Ocimum gratissimum in the treatment of acne [19], Drechslera rostata and Polygala molluginifolia for their antitumor activities [20, 21]. Medicinal plants including Ageratum conyzoides, Celosia trigyna, Centella asiatica, Brassica nigra, Racunculus oreophytus, Azadiracha indica, Ficus exasperate, Senna hirsuta, Morus alba, Artocarpus heterophyllus have all been reported for their ethnomedicinal use in various ethnic groups [22-24].

Microbial resistance has increased with drug discovery resulting in serious health concerns globally $[25,26]$ and indiscriminate use of antimicrobial remains the main cause [27]. Therefore, the emergence of multidrug resistant microbes in water and undesirable effects of conventional antimicrobials call for alternative means of water treatment of plant origin [28]. Various microbial contamination of human origin in water may be controlled by extracts of plants [29]. In Kirui et al. [30]. Aqueous extract of Acacia nilotica, Acacia seyal, Acacia tortilis, Acacia etbaica, Albizia anthelmintica, Euclea divinorum and Plumbago zeylanica were investigated for their water treatment capacity and report indicates a notable effect. Extracts of Moringa oleifera, Jatropha curcas and Guar gum have also been investigated for their water treatment potential and reduction in turbidity of the treated water was observed [31]. These observations show the potential of plant product for water treatment. This attempts made to finding alternative way to combat resistant microorganisms and water disinfection is noble. It is of low cost and mostly available for safe water especially, in Africa. This review discusses the prospects of plant and plant products in less reported areas of water and antimicrobial resistance interventions.

\section{Methodology}

A desktop structured study of scholarly published articles was employed in the study of over 200 relevant literatures. The searched databases included Science Direct, Google Scholar and Web of Science. The searched terms and keywords included history, types, mechanisms of action, standardisation and application of phytobiotics in various fields. The search was restricted to articles written in English language and covered the period between 1993 and 2020. A review of studies reporting the use of plants as alternative against resistant microorganism especially in water treatment was attempted. Studies reporting the mechanisms of action of phytobiotics, methods employed in standardisation of herbal drug and current existing challenges in this field were examined. Raw information obtained were computed in MS-excel 2016 to convert data into processed statistics for the interpretation of the data. Tables, figures charts and simple percentages were used to present and interpret the results of data.

\section{Results and discussion}

Classification of synthetic and plant-based antimicrobials The treatment of microbial infections and contamination has mainly involved the use of antimicrobial agents like antiseptics, sanitizers, disinfectants, as well as antibiotics [32]. Antibiotic could specifically denote a substance with the capacity to inhibit, that is, cause static or cidal effect to microbes at low concentrations [33]. Pharmaceutical agents such as antibacterial, antifungal, antiviral, and antiparasitic drugs are broadly referred to as antibiotics [34]. Among the several classification schemes for antibiotics, those based on the molecular structures, spectrum of activity and modes of action [35] are more preferred as indicated in Table 1. Antibiotics can also be classified as injectable, oral or topical based on route of administration. Antibiotics with similar structure will usually exhibit similar trends of actions and effects.

The antimicrobial activity of plants has been credited to the existence of phytochemicals in specific parts of plants [38] where they contribute to enhanced plant's survival by warding off pathogenic microorganisms [39, 40]. Some major groups of antimicrobials derived from plants include saponins, polyphenols, alkaloids, lectins, tannins, flavonoids, and terpenoids [41]. Synthetic pathways of some phytochemicals and related enzymes are indicated in Fig. 1.

\section{Basic phenolic acids and phenols}

These are made of mono-substituted ring of phenol [43]. It is thought that the site(s) as well as numbers of hydroxyl components in this group influence the level of toxicity against microorganisms as it is evident that higher hydroxylation correlates with improved toxicity [44]. When phenolics possess a lower level of oxidation and a $C_{3}$ side chain, it is referred to as an essential oil [45]. This group includes cinnamic acids, caffeic acids, and pyrogallol with proven toxicity against microbes. The defensive functions of phenolic compounds in plants include antimicrobial activities as well as cell wall repair and strength [46]. 
Table 1 Existing groups of antibiotics and their characteristics

\begin{tabular}{lll}
\hline Molecular structure & Action site/target & Spectrum of activity \\
\hline Beta-lactams & Cell wall & Wide, Narrow \\
Quinolones & Nucleic acid synthesis & Narrow \\
Sulfonamides & Cell metabolite synthesis & Wide \\
Aminoglycosides & Cell Protein production & Narrow, Wide \\
Oxazolidinones & Cell protein production & Wide \\
Glycopeptides & Cell wall synthesis & Narrow \\
Macrolides & Cell protein production & Wide \\
Tetracyclines & Inhibition of protein synthesis & Broad \\
\hline
\end{tabular}

Source: $[36,37]$

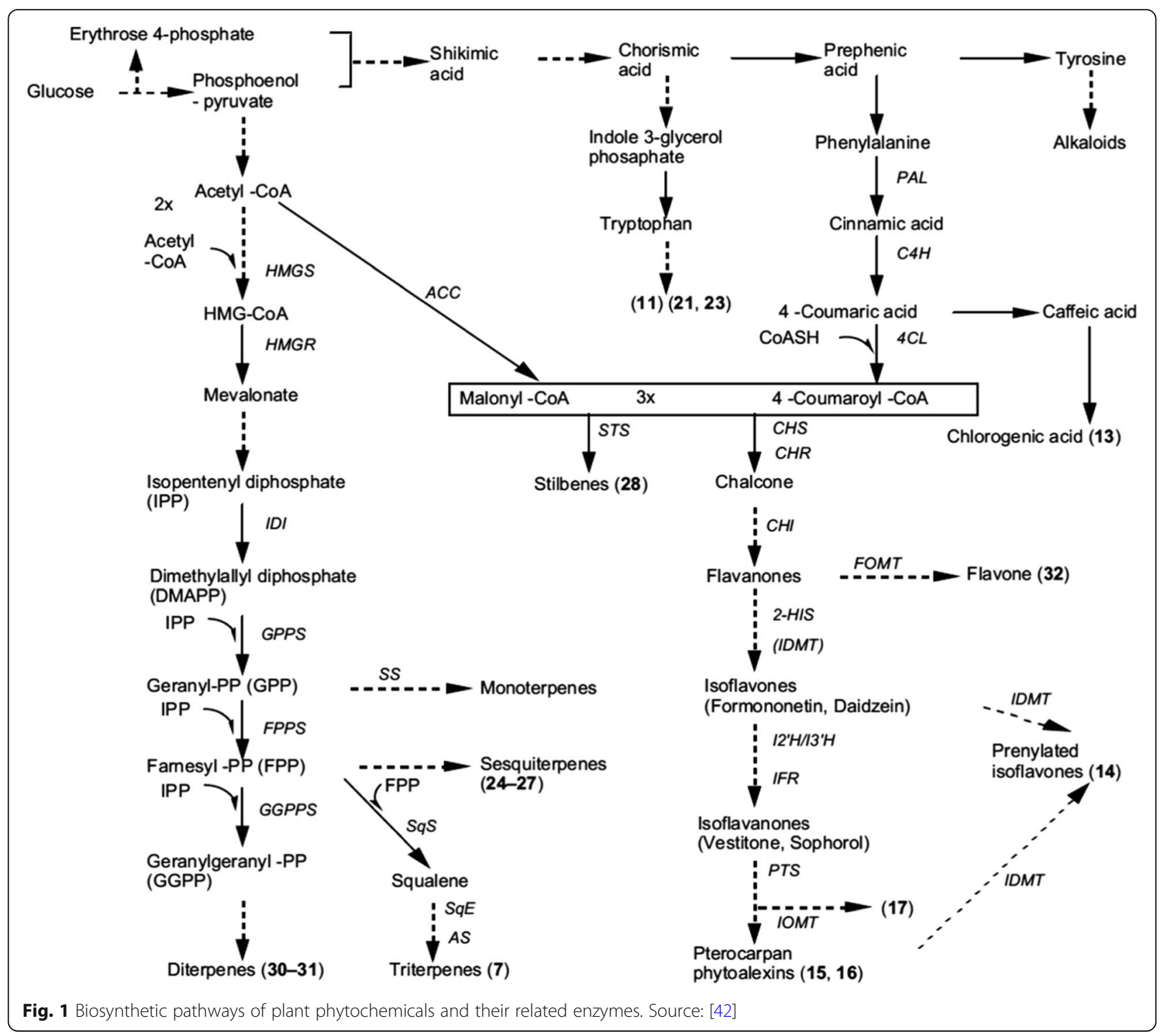




\section{Quinones}

These are classes of cyclic organic compounds with two carbonyl groups characterised with high reactivity and ubiquity. They possess aromatic rings and 2 ketone substitutes viewed as an important phytochemical group and possess excellent antimicrobial activities [5]. Quinones are responsible for the natural activity of browning reaction on plant. In microbial cell, quinones target surface-exposed adhesins, membrane bound enzymes and cell wall polypeptides [45]. Quinones may as well render substrate unavailable to microorganisms. An example is anthraquinone with a wide spectrum of antimicrobial actions [5].

\section{Flavonols and flavones}

These classes of flavonoids possess a double bond between position 2 and 3, and oxygen (a ketone group) in position 4 of the $\mathrm{C}$ ring (Fig. 2). Flavones have demonstrated excellent antibiosis against broad groups of microbes [47]. Reported antiviral and other bioactive effects of these groups of phytochemicals include the action of herperetin, galangin and alpinumisoflavone against Human Immunodeficiency Virus, poliovirus type 1 , gram positive bacteria, fungi, and schistosomal infections [46].

\section{Tannins}

Tannins are poly-phenolics with wide distribution in various plant parts and are involved in many physiological activities of plant such as stimulation of phagocytic cells and anti-infective activities [47]. The antibacterial activities of tannins are attributed to their capacity to disrupt bacterial enzymes, cell envelope, adhesins and transport proteins. They are toxic to fungi, bacteria and yeasts cells [5]. Their strong affinity for iron on cell membrane results in inactivation of membrane-bound protein, which is responsible for wide antibacterial activities of gallotannin containing plants [49].

\section{Coumarins}

These are phytochemicals with bonded alpha pyrone and benzene. Coumarins may exhibit selective antiviral effects. Warfarin is a commonly reported coumarin which produces diverse biological activities and has been

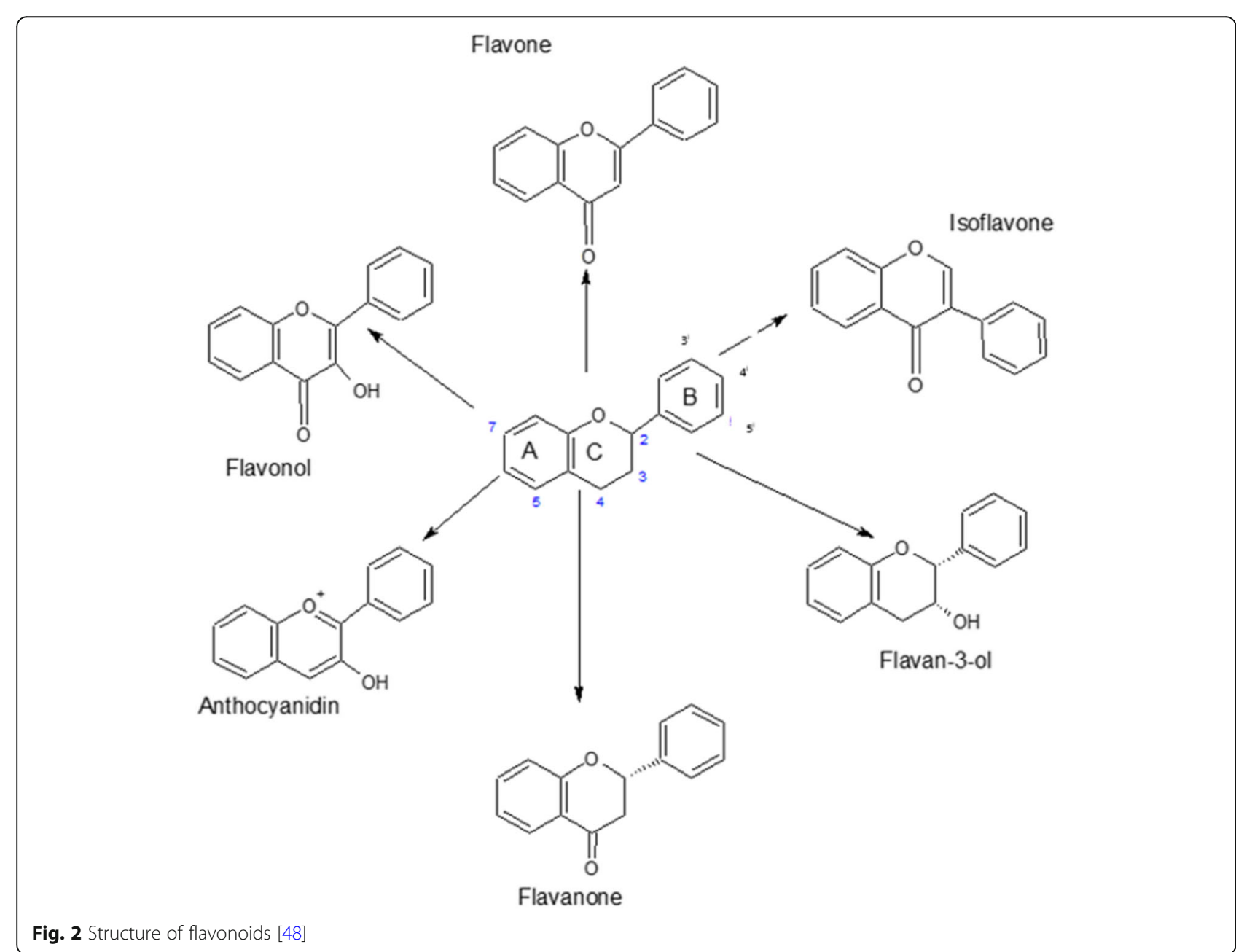


proved in-vitro to inhibit the growth of Candida albicans [47]. They can stimulate macrophages and reduce tenacity of microbial infection. Warfarin has also been a prescribed drug therapy for prevention of thromboembolic conditions for decades [50]. Esculetin, 6-nitro7-hydroxycoumarin, scopoletin, 7,8 -dihydroxy-4methylcoumarin have also been reported for cytotoxicity activity against cancer cell lines [51].

\section{Alkaloids}

Alkaloids are nitrogenous heterocyclic compounds. The first medically engaged alkaloid- morphine, was obtained from Papaver somniferum. This group of phytochemicals proved to be microbiocidal (against Entamoeba spp. and Giardia) and are antidiarrheal. Examples of alkaloids include diterpene alkaloids, berberine (isoquinoline alkaloid) and solamargine (glycoalkaloid) used against a wide range of fungi, protozoa, bacteria, viruses and in maintenance of HIV [5, 52]. They penetrate cells, intercalate DNA and target several nucleic acid enzymes, resulting in severe damages to microbial cells [53].

\section{Emerging interventions of phytobiotics Intervention in water treatment}

The use of plant derivatives as microbial inhibitors has been greatly reported [54-57]. However, limited literatures exist on the application of plant as disinfectants in water treatment. Winward et al. [58] reported the antimicrobial activity of 8 mixtures of different plant extracts which were studied for disinfection of coliform in grey water. Another study using thyme oils recorded higher inactivation of $E$. coli when compared to chlorinedioxide and ozonation for disinfection of water [59]. Extracts of plants such as M. oleifera, J. curcas, Guar gum [60], Terminalia glaucescens, Zanthoxylum zanthoxyloides, Gongronema latifolium [61, 62], Azadirachta indica oil extracts [63] and Luffa cylindrica fruit extracts [64] have been reported for use in water treatment. It must be noted that high concentrations of crude plant extracts are not desired in water treatment since they result into undesired amount of suspended solids and contribute to taste and colour development. Hence, purified active plant-derived compounds rather than crude extracts or powders are preferred for water treatment.

\section{Interventions in microbial resistance}

Arctostaphylos uvaursi, Vaccinium macrocarpon, Hydrastis canadensis as well as oil extracts of Melaleuca alternifolia and Echinacea species have been used for the treatment of microbes of urinary tract, skin and lung origin $[56,65]$. Curative potential of plant extracts has been investigated and developed as novel drugs to control microbial infections and those with minimum inhibitory concentration of $100-1000 \mathrm{mg} / \mathrm{ml}$ are accepted and classed as antimicrobials [56]. Reports by various investigators had confirmed the antimicrobial potency of different plant materials [66]. Plants like Holarrhenea antidyssentrica [67], Tapinthus senssilifolius [68], Psidium guajava, Mangifera indica [69], Rauelfia tetraphylla, Physalis minima [70], Salvia spp. [71] and Salicornia brachiata [72] have demonstrated antimicrobial effects.

Plant products have been considered as alternatives to synthetic counterparts with significant results, including commercial antiseptics [73], sanitisers [74] and antibiotics [75]. Several other plant materials and formulations have been tested against different bacterial and fungal isolates with satisfactory results in literature [76-79]. Furthermore, plants active compounds have been considered useful in cases of multidrug resistance [80] and inhibition of biofilm formation [81]. Selected plants bioactivities against multi-drug resistant microbes are presented in Table 2. They have been considered for their effects in efflux pump inhibition [82]. Fungi as well as bacteria have all been treated by several plant compounds, reducing their virulence and pathogenicity through modulation of gene transcription, expression of proteins and quorum sensing [83-89].

Plant products are also considered in adjuvant application. Since phytochemicals possess varied minimum inhibitory concentrations (MIC) from synthetic antibiotics, phytochemicals may be a good adjuvant for potentiating the activities of conventional biocides to improve efficacy and reduce the dosage of synthetic disinfectants $[93,94]$. Many reviews have dealt with reports on system of actions of plant materials and extensive list of herbs with antimicrobial activity exists [95-105]. Some examples of interventions of phytobiotics as antimicrobial are presented in Table 3.

\section{Mechanisms of action of antibiotics and phytobiotics}

Diverse mechanisms exist to define the actions of phytochemicals in different bioactivities. They may prevent the growth of microorganisms, interfere with some biological metabolic processes or may modulate signal transduction and gene expression pathways [110-112]. Multiple molecular targets of phytochemicals have been identified to include cell cycle proteins, cell adhesion molecules, protein kinases, transcription factors and cell growth pathways [113-115]. Multi-molecular targets of plant phytochemicals account for multi-mechanisms of action in plant product [116]. Phytochemicals may modulate transcription factors [117], redox-sensitive transcription factors [118], redox signalling, and inflammation.

The general antimicrobial activities of conventional antimicrobials are hinged on inhibition of several cellular 
Table 2 Overview of extracts with efficacy against resistant microorganisms

\begin{tabular}{|c|c|}
\hline Extract types & Record against resistant microbes \\
\hline Alpha mangostin from Gracinia mangostana & Vancomycin resistant enterococci (VRE) \\
\hline $\begin{array}{l}\text { Ethanolic extract of Ocimum gratissimum, Vernonia amygdalina, Zingiber } \\
\text { officinale, }\end{array}$ & MDR E. coli, S. aureus, P. vulgaris, B. subtilis, S. typhimurium \\
\hline $\begin{array}{l}\text { Methanolic extracts from Boswellia papyrifera, Caesalpinia coriaria, Psidium } \\
\text { guajava, Commiphora molmol and Centratherum punctatum }\end{array}$ & $\begin{array}{l}\text { Klebsiella pneumonia, MDR Staphylococcus aureus, Methicillin-resistant } \\
\text { Staphylococcus aureus (MRSA), MDR Acinetobacter baumannii }\end{array}$ \\
\hline $\begin{array}{l}\text { Ethanolic extracts of Pelargonium sidoides, Acacia nilotica, Cinnamomum } \\
\text { zeylanicum, Syzygium aromaticum, Allium sativum and Cinnamomum } \\
\text { cassia. }\end{array}$ & $\begin{array}{l}\text { A. niger, E. coli, K. pneumoniae, Candida albicans, Extensively drug- } \\
\text { resistant (XDR) M. tuberculosis and Multi-drug resistant Pseudomonas } \\
\text { aeruginosa }\end{array}$ \\
\hline Alkaloid fraction of Prosopis juliflora & Acinetobacter \\
\hline Methanolic and ethanolic extracts of Chromolaena odorata & MDR S. aureus, P. aeruginosa, K. pneumoniae \\
\hline Aqueous extract of Thonningia sanguine & ESBL-producing E. coli \\
\hline Aqueous extract of Allium sativum & MDR S. aureus, S. epidermidis, S. pneumonia, S. typhi, E. coli \\
\hline Ethyl acetate extracts of $C$. punctatum & MDR Acinetobacter baumannii \\
\hline
\end{tabular}

Source: [80, 90-92]

functions and structure, including cell membrane function, cell wall synthesis, nucleic acid and protein synthesis, as well as blockage of key metabolic pathways. Phytochemicals act majorly by collapsing cell walls and membranes, resulting in leakage of the cell component, interruption of proton motive force, dysfunction of efflux pump and enzymes, all leading to cytosis [119]. Some phytochemicals inhibit or minimise quorum sensing and this signifies a feasible method of countering antibiotic resistance in microorganisms since quorum sensing is partly involved in the mechanism of antibiotic-resistance in microbes [120].

A group of cell membrane disruptors include amphotericin B, polyenes, imidazole, triazole and polymyxins [36]. This group disrupts the structure of the membrane in cytoplasm of microorganisms resulting in the escape of macromolecules and ion from the cell, which results in lethal effects [121]. Antibiotics inhibiting cell wall synthesis are vancomycin, bacitracin, penicillin and cephalosporin. These antibiotics manipulate specific steps in homeostatic cell wall biosynthesis, in inhibition of peptide bond formation reaction catalysed by transglycosylase and transpeptidases and then activation of autolytic enzymes [122]. Antibiotics can block nucleic acid replication and halt transcription by inhibition of DNA polymerase, helicase or RNA polymerase. Examples are rifampin, trimethoprim, quinolones and sulphonamides $[37,123]$.

Antibiotics inhibiting protein synthesis may either block the initiation of protein translation or peptidyl tRNAs translocation, which inhibit peptidyltransferase reaction involved in elongating the nascent peptide chain [124]. Examples of protein inhibiting antibiotics are chloramphenicol, tetracycline, erythromycin, lincomycin, and aminoglycosides. Some antibiotics like sulphonamides and trimethoprim mimic important substrate needed for cellular metabolism in microbes. This deception results in microbial enzyme attachment to antibiotic rather than the needed substrate [125] resulting in blockages of key metabolic pathways of survival. An example of metabolic pathway blocking antibiotics is sulfonamides, which are structurally identical to $p$ aminobenzoic acid needed in the synthesis of folic acid, thus disrupting the nucleic acid synthesis and amino acid production, since they imitate materials needed for folic acid metabolism [125].

Table 3 Medicinal plants and their antimicrobial intervention

\begin{tabular}{lll}
\hline Botanical names & Activity & References \\
\hline Tuberaria lignosa & Antiviral activity & {$[10]$} \\
Cymbopogon citratus & Antibiofilm activity & {$[81]$} \\
Rauvolfa vomitona & Efflux pump inhibition & [82] \\
Cymbopogon citratus & Antibiofilm activity & {$[105]$} \\
Berberis aristata & Microbial virulence attenuation & {$[106]$} \\
Chromolaena odorata & Adjuvant therapy & {$[107]$} \\
Mangifera indica & Adjuvant therapy & {$[108]$} \\
Andrographis paniculata & Antiral activity & {$[109]$} \\
\hline
\end{tabular}


Conventional chemically synthesised antibiotics and phytobiotics significantly differ with respect to frequency in spatial arrangement and radical composition [126]. The latter is with less nitrogen, phosphorus, sulphur, halogens and exhibit diverse and enhanced scaffold formation, stereo-chemical conformation, molecular complexity, varied ring system and carbohydrate compositions [127]. Furthermore, phytochemicals can disrupt protein-protein reactions and act as immune modulators and modulators of mitosis with less resistance from microbes due to the aforementioned complexity of plant phytochemicals [128]. Plant phytochemicals therefore exert activities via highly complex and diverse mechanisms, including disruption in cell quorum sensing, membranes, structures, nucleic acid synthesis, cytoplasmic material and cell metabolism [129133]. A common phenomenon is that several compounds in crude plant extract act at different target sites in pathogens and contribute to optimum efficacy of plant extracts. Phytochemicals may exhibit antimicrobial effect in microbes not only through direct lethal activity, but also by altering key events in pathogenesis [134].

\section{Standardisation of phytobiotics}

Herbs comprise of crude plant materials such as fruits, flowers, stems, wood, leaves, seeds or other parts of plants in whole or parts. Herbal products are prepared through different carefully selected processes of solvent extraction and purification, and more recently by novel advanced instrumentation techniques by physical, chemical and biological processes alone or in combination with conventional extraction process. Products which have been modified with synthetic compounds or other chemically defined, active substances as well as isolated constituent from herbal materials may not wholly be accepted as herbal [135].

Standardisation in phytomedicine refers to the procedure for ensuring quality, standard characteristics, persistent nature and absolute quantifiable values with a guarantee of effectiveness, non-toxicity, excellence and reproducibility [136]. Validation of herbal drugs and recognition of counterfeits from quality herbal products are necessary for public health and quality reproducibility in herbal medicine. Standardisation reduces batch differences, guarantee effectiveness, originality, safety and acceptability of herbal products [137]. Some recent techniques of herbal standard verification include Thin Layer Chromatography, High Performance Thin Layer Chromatography, Gas Chromatography, Super Critical Fluid Chromatography, Chromatographic Fingerprinting and DNA Fingerprinting. Brief details on herbal drug standardisation are given in Table 4.

\section{Studies on commercial disinfectant for water treatment} When choosing a disinfectant for water processing, there is a need to consider if it follows all regulatory approvals [146]. Through the use of disinfectants, pathogenic (resistant) bacteria present in water can be destroyed to make water safe for drinking [147]. Plant disinfectants have also been produced as alternative to the chemical disinfectant counterparts. Tannins, plant gums and celluloses are examples of plant products that have been reported as effective natural disinfectants [148, 149]. Tannins are produced from polyphenolic metabolites from bark, fruits and leaves of plants [150]. Mimosa bark tannin, quebracho wood tannin, pine bark tannin and eucalyptus species bark tannin are common tannins used in for water treatment. The coagulation effect of tannins have been tested for the treatment of raw water in the

Table 4 Various techniques for herbal drug analysis

\begin{tabular}{|c|c|}
\hline Method & Application \\
\hline Thin Layer Chromatography & $\begin{array}{l}\text { Used in the assessment of herbal drugs, TLC is commonly engaged [138] since it allows rapid analysis with } \\
\text { easy sample preparation need. It supplies semi-quantitative and qualitative details and may provide informa- } \\
\text { tion on quantity and composition of phytochemicals [139]. }\end{array}$ \\
\hline $\begin{array}{l}\text { High Performance Thin Layer } \\
\text { Chromatography: }\end{array}$ & $\begin{array}{l}\text { This is usually engaged to study compounds with less polarities. It is commonly used for identification and } \\
\text { recognition of counterfeit products and assists in quality control of herbal and health products [140]. }\end{array}$ \\
\hline Gas Chromatography: & $\begin{array}{l}\text { The basis of gas chromatography separation is the redistribution of compounds between a support stationary } \\
\text { and gaseous mobile phase material. Gas chromatography is greatly in use to separate and identify volatile } \\
\text { phytochemicals in plant materials [141]. }\end{array}$ \\
\hline $\begin{array}{l}\text { Super Critical Fluid } \\
\text { Chromatography }\end{array}$ & $\begin{array}{l}\text { This technique combines the features of gas and liquid chromatography. It handles processing of compounds } \\
\text { that cannot be easily determined by conventional gas and liquid chromatography [142]. }\end{array}$ \\
\hline Chromatographic Fingerprinting & $\begin{array}{l}\text { When similar herbal drugs are developed from similar chemical component but possess different identifiable } \\
\text { chemical characteristics, chromatographic fingerprinting can be used to resolve the differences. It uses } \\
\text { chromatography profiles obtained from extracts' chemical components to establish similarities and differences } \\
\text { between plant products. The validation and identification of herbal products can be perfectly resolved even } \\
\text { when the chemical constituents are difficult to handle in complex situations [143]. }\end{array}$ \\
\hline DNA Fingerprinting & $\begin{array}{l}\text { This is an important tool engaged when phytochemically unresolvable adulterated parts of plant are used in } \\
\text { imitation for the genuine products. The availability of intact genomic DNA from plant samples after processing } \\
\text { is the key for using DNA fingerprinting to resolve processed drug samples with unresolvable phytochemical } \\
\text { similarities }[144,145] \text {. }\end{array}$ \\
\hline
\end{tabular}


removal of suspended and colloidal materials, removal of dyes, pigments as well as inks from ink-containing wastewater [151, 152].

Flocculants have also been derived from several plants gums and mucilages. These are obtained after aqueous extraction, precipitation with alcohol and drying. It has been used in the treatment of landfill leachate, textile wastewater, tannery effluent and sewage effluent $[153,154]$. From the report from Agarwal et al. [155], result showed $85 \%$ removal of suspended solids and $90 \%$ colour removal using these plant-based products. Cellulose is another alternative to synthetic disinfectant in water purification. Its water purification effect is due to the abundant free $-\mathrm{OH}$ groups on the chain that enables the removal of metal ions and organic matter from water [156]. However, the use of cellulose is limited because of its poor solubility and low chemical reactivity. This disadvantage can be taken care of by carboxymethylation [157].
Commercially, Tanfloc have been produced by a Brazilian company, and TANAC from the bark of Acacia tree [158]. Tanfloc allows for the removal of biological oxygen demand and chemical oxygen demand and generates a sludge volume that is biodegradable. Tanfloc has been tested to remove heavy metals from polluted surface water and municipal wastewater [150]. Another company in Italy, Silvateam also produced a commercially available plant based disinfectant called SilvaFLOC from the bark of $S$. balansae. Silvafloc has been tested on surface river water and has been reported safe for use in drinking water treatment [159]. It is found to be more efficient than aluminium sulphate for water clarification.

\section{Data analyses}

Reported use and chemical components of some plants are presented in Tables 5 and 6 . A total of 44 plants are presented in Table 6 with members of the family, Compositae mostly reported. Compositae (asteraceae) is the

Table 5 Chemical components and target microbial group of some medicinal plants

\begin{tabular}{|c|c|c|c|c|c|c|}
\hline Botanical name & Family name & $\begin{array}{l}\text { English } \\
\text { name }\end{array}$ & Plant part & Chemical components & $\begin{array}{l}\text { Target } \\
\text { microorganism(s) }\end{array}$ & Reference \\
\hline Allium cepa & Alliaceae & Onion & Leaves, bulb & $\begin{array}{l}\text { Chrysophanol, aloe-emodin, hydroxyl-2,5- } \\
\text { dimethylchromone, Aloin A and B, Aloesin, } \\
\text { Aloenin B, 10-hydroxyaloin B }\end{array}$ & Candida & $\begin{array}{l}\text { Shams- } \\
\text { Ghahfarokhi } \\
\text { et al. [165] }\end{array}$ \\
\hline Aloe barbadensis & Aloeaceae & $\begin{array}{l}\text { Burn plant, } \\
\text { Aloe vera, } \\
\text { medicinal } \\
\text { aloe }\end{array}$ & Leaves & $\begin{array}{l}\text { Barbaloin, chrysophanol glycoside, } \\
\text { aglycone, aloe-emodin, aloesone, aloesin }\end{array}$ & $\begin{array}{l}\text { Corynebacterium, } \\
\text { Salmonella, } \\
\text { Streptococcus }\end{array}$ & $\begin{array}{l}\text { Athiban } \\
\text { et al. [166] }\end{array}$ \\
\hline $\begin{array}{l}\text { Cassia } \\
\text { angustifolia }\end{array}$ & Caesalpiniaceae & Senna & $\begin{array}{l}\text { Pods, fruit, } \\
\text { stems, leaves }\end{array}$ & $\begin{array}{l}\text { Oxymethylanthraquinone, flavanols, } \\
\text { isorhamnetin, Kaempferol, rhein, emodin, } \\
\text { sennosides, aloe-emodin, emodin glucoside }\end{array}$ & $\begin{array}{l}\text { Staphylococcus } \\
\text { aureus }\end{array}$ & $\begin{array}{l}\text { Singanboina } \\
\text { et al. [167] }\end{array}$ \\
\hline Glycyrrhiza glabra & Papilionaceae & Mulaithi & Root & $\begin{array}{l}\text { Glycyrrhizin, glycyrrhetic acid, isoliquiritin, } \\
\text { isoflavones }\end{array}$ & $\begin{array}{l}\text { Staphylococcus } \\
\text { aureus, } \\
\text { Mycobacterium } \\
\text { tuberculosis }\end{array}$ & $\begin{array}{l}\text { Varsha et al. } \\
\text { [168] }\end{array}$ \\
\hline Lawsonia inermis & Lythraceae & Heena & Leaves, seeds & $\begin{array}{l}\text { Lawsone, 2-hydroxy-1, 4-napthoquinone } \\
\text { resin, tannin, gallic acid, saponin, trim- } \\
\text { ethylamine, sterols }\end{array}$ & $\begin{array}{l}\text { Staphylococcus } \\
\text { aureus }\end{array}$ & $\begin{array}{l}\text { Habbal et al. } \\
\text { [169] }\end{array}$ \\
\hline $\begin{array}{l}\text { Panax } \\
\text { notoginseng }\end{array}$ & Araliaceae & $\begin{array}{l}\text { Chinese } \\
\text { ginseng, } \\
\text { notoginseng }\end{array}$ & Root & $\begin{array}{l}\text { Saponin, flavonoids, polyacetylenes, } \\
\text { peptides, ginsenosides, polysaccharides }\end{array}$ & $\begin{array}{l}\text { Escherichia coli, } \\
\text { Sporothrix } \\
\text { schenckii, } \\
\text { Trichophyton }\end{array}$ & $\begin{array}{l}\text { Wang et al. } \\
\text { [170] }\end{array}$ \\
\hline $\begin{array}{l}\text { Rabdosia } \\
\text { trichocarpa }\end{array}$ & Lamiaceae & $\begin{array}{l}\text { Dong ling } \\
\text { cao }\end{array}$ & Leaves & $\begin{array}{l}\text { Sodoponin, ponicidin, oridonin, odonicin, } \\
\text { lasiodonin, lasiokaurinol, rubescensin C, } \\
\text { rabdosin A, Ememogin }\end{array}$ & Helicobacter pylori & $\begin{array}{l}\text { Kadota et al. } \\
{[171]}\end{array}$ \\
\hline Rumex crispus & Polygonaceae & $\begin{array}{l}\text { Curly dock, } \\
\text { yellow dock }\end{array}$ & $\begin{array}{l}\text { All parts } \\
\text { although the } \\
\text { root is the most } \\
\text { active }\end{array}$ & $\begin{array}{l}\text { Beta-sitosterol, hexadecanoicacid, } \\
\text { chrysophanol, physcion, emodin, catechin }\end{array}$ & $\begin{array}{l}\text { Escherichia coli, } \\
\text { Salmonella, } \\
\text { Staphylococcus }\end{array}$ & $\begin{array}{l}\text { Wegiera } \\
\text { et al. [172] }\end{array}$ \\
\hline $\begin{array}{l}\text { Santolina } \\
\text { chamaecyparissus }\end{array}$ & Asteraceae & $\begin{array}{l}\text { Cotton } \\
\text { lavender }\end{array}$ & Leaves, flowers & $\begin{array}{l}\text { Artyemisia ketone, dihydroaromadendrene, } \\
\beta \text {-phellandrene }\end{array}$ & $\begin{array}{l}\text { Gram positive } \\
\text { bacteria, Candida }\end{array}$ & $\begin{array}{l}\text { Salah- } \\
\text { Fatnassi } \\
\text { et al. [173] }\end{array}$ \\
\hline $\begin{array}{l}\text { Taraxacum } \\
\text { officinale }\end{array}$ & Asteraceae & Dandelion & Leaves & $\begin{array}{l}\text { Phytosterols, sesquiterpene lactones, } \\
\text { flavonoids, aremetin, quercetin, luteolin }\end{array}$ & $\begin{array}{l}\text { Streptomuces } \\
\text { cerevisiae, Candida } \\
\text { albicans }\end{array}$ & $\begin{array}{l}\text { Liang et al. } \\
\text { [174] }\end{array}$ \\
\hline
\end{tabular}


Table 6 Reported uses of some plants

\begin{tabular}{|c|c|c|c|c|}
\hline Botanical Name & Family & Plant part used & Target Antimicrobial action & References \\
\hline Acacia nilotica & Leguminosae - Mimosoideae & Whole plant & Water treatment & {$[30]$} \\
\hline Acacia seyal & Leguminosae - Mimosoideae & Whole plant & Water treatment & {$[30]$} \\
\hline Acacia tortilis & Leguminosae - Mimosoideae & Whole plant & Water treatment & {$[30]$} \\
\hline Acacia etbaica & Leguminosae - Mimosoideae & Whole plant & Water treatment & [30] \\
\hline Abizia anthelmintica & Leguminosae - Mimosoideae & Whole plant & Water treatment & [30] \\
\hline Euclea divinorum & Ebenaceae & Whole plant & Water treatment & [30] \\
\hline Plumbago zeylanica & Plumbaginaceae & Whole plant & Water treatment & {$[30]$} \\
\hline Moringa oleifera & Moringaceae & Seeds & Water treatment & [31] \\
\hline Jatropha carcus & Euphorbiaceae & Seeds & Water treatment & [31] \\
\hline Guar gum & Fabaceae & Seeds & Water treatment & [31] \\
\hline Moringa oleifera & Moringaceae & Seeds & Water treatment & {$[60]$} \\
\hline Jatropha carcus & Euphorbiaceae & Seeds & Water treatment & {$[60]$} \\
\hline Guar gum & Fabaceae & Seeds & Water treatment & {$[60]$} \\
\hline Achillea millefolium & Compositae & Whole plant & Antimicrobial & {$[175]$} \\
\hline Allium cepa & Alliaceae & Bulb & Antimicrobial & {$[176]$} \\
\hline Allium sativum & Alliaceae & Bulb & Antimicrobial & [177] \\
\hline Anemone pulsatilla & Ranunculaceae & Whole plant & Antimicrobial & [178] \\
\hline Ranunculus bulbosus & Ranunculaceae & Whole plant & Antimicrobial & [178] \\
\hline Anethum graveolens & Umbellifferae & Seed & Antimicrobial & [179] \\
\hline Artemisia dracunculus & Compositae & Leaves & Antimicrobial & [180] \\
\hline Moringa oleifera & Moringaceae & Seeds & Water treatment & [181] \\
\hline Luffa cylindrica & Cucurbitaceae & Seeds and fruit & Water treatment & [182] \\
\hline Moringa oleifera & Moringaceae & Seeds and leaves & Water treatment & [183] \\
\hline Berberis vulgaris & Berberidaceae & All parts (mostly root) & Antimicrobial & [184] \\
\hline Calendula officinalis & Compositae & All parts (mostly leaves) & Antimicrobial & [185] \\
\hline Camellia sinensis & Theaceae & Leaves & Antimicrobial & [186] \\
\hline Cannabis sativa & Cannabidaceae & Leaves, resin & Antimicrobial & [187] \\
\hline Capsicum annuum & Solanaceae & Fruit & Antimicrobial & [188] \\
\hline Carum carvi & Umbelliferae & Seed & Antimicrobial & [189] \\
\hline Citrus sinensis & Rutaceae & Fruit & Antimicrobial & [190] \\
\hline Coriandrum sativum & Umbelliferae & Seed & Antimicrobial & [191] \\
\hline Eucalyptus globules & Myrtaceae & Leaves & Antimicrobial & [192] \\
\hline Humulus Iupulus & Cannabidaceae & Fruit & Antimicrobial & [193] \\
\hline Hydrastis Canadensis & Ranunculaceae & Whole plant & Antimicrobial & [194] \\
\hline Hyssopus officinalis & Labiatae & Leaves & Antimicrobial & [195] \\
\hline Laurus nobilis & Lauraceae & Leaves & Antimicrobial & [196] \\
\hline Malus sylvestris & Rosaceae & Fruit, leaves, bark & Antimicrobial & [197] \\
\hline Matricaria chamomilla & Compositae & Flowers & Antimicrobial & [198] \\
\hline Melissa officinalis & Labiatae & Leaves, flowers & Antimicrobial & [199] \\
\hline Peganum harmala & Zygophyllaceae & Fruit, seed & Antimicrobial & {$[200]$} \\
\hline Solanum tuberosum & Solanaceae & Tuber & Antimicrobial & [201] \\
\hline Thymus vulgaris & Labiatae & All part & Antimicrobial & [202] \\
\hline Tussilago farfara & Compositae & All part & Antimicrobial & [203] \\
\hline Vicia faba & Leguminosae & Seed pod & Antimicrobial & [204] \\
\hline
\end{tabular}


most diverse family of angiosperms and has a worldwide distribution. The family has been reported for its enormous importance in popular medicine and is the major plant studied for use in many ethno-medicinal researches [160-162]. The family Compositae is nested high in the Angiosperm phyleny. The family contains the largest number of described, accepted species of any plant family [163]. The diverse application of Compositae has been attributed to the wide array of bioactive component they contain as well as the higher likeliness of the people to experiment with members of this family. Conversely, the survey by Lawal et al. [164] reveals the family Leguminosae as the mostly used family and that compositae was barely used. However, Ageratum conyzoides and Vernonia amygdalina, both of which belong to the family Compositae were reported as commonly used species ethno-medicinally.

During the survey, it was apparent that whole plants and seeds (24.53\%) are mostly used. Since individual plant parts have been reported for effective activity, the whole plant biomass is assumed to possess better activity and may account for the high value of whole plant material use as compared to other plant parts. The use of whole plants is usually not preferred since the removal of whole plant threatens conservation of plant species. The seeds (24.53\%), flowers (20.75), leaves (16.98\%) and fruit $(11.32 \%)$ are therefore preferable as observed in Fig. 3 as against bulb (3.77\%), resin (1.89\%), bark (1.89\%) and tuber $(1.89 \%)$. This result does not align with the findings of Ozioma et al. [205] who reported leaves to possess more effective properties than other parts. As established by Ullah et al. [206], leaves are more reportedly used and followed by fruit (15\%) among plant parts used during an indigenous study. Leaves, roots and bulbs are the most desirable parts because they contain a high concentration of bioactive compounds. Compared with the whole plant and roots, the use of leaves or arial part of plant is much better for sustainability of natural plant products and biotechnology [207]. The use of plant products in water treatment needs to gain more research attention as they can be effective alternatives for conventional agents of water disinfection. The observation in Fig. 4 suggests that novel applications of plant products need to be explored further since more antimicrobial activities (63.63\%) exist for plant materials than water treatment application (36.37\%). Moringa seeds have been greatly studied for water treatment due to the presence of cationic proteins (dimeric) responsible for their anticoagulant potential [208, 209]. Moringa oleifera extracts as well as other natural coagulants are presently in demand because they are less toxic and ecofriendly [183]. Reports have also shown that combined treatment can present better coagulation effect as seen in Alam et al. [183] report. There is always a need to carry out test to ascertain the toxicity of plants extracts to be used in water treatment and ensure its effect falls within the WHO guideline values, to be proved effective [60].

\section{Current challenges}

There are current issues which call for caution during herbal and plant products usage. Safe plants and those with positive health effects must be identified prior to use and product formulation in water disinfection. Regulations in herbal remedies and isolation of pure and safe compounds rather than crude usage may be necessary

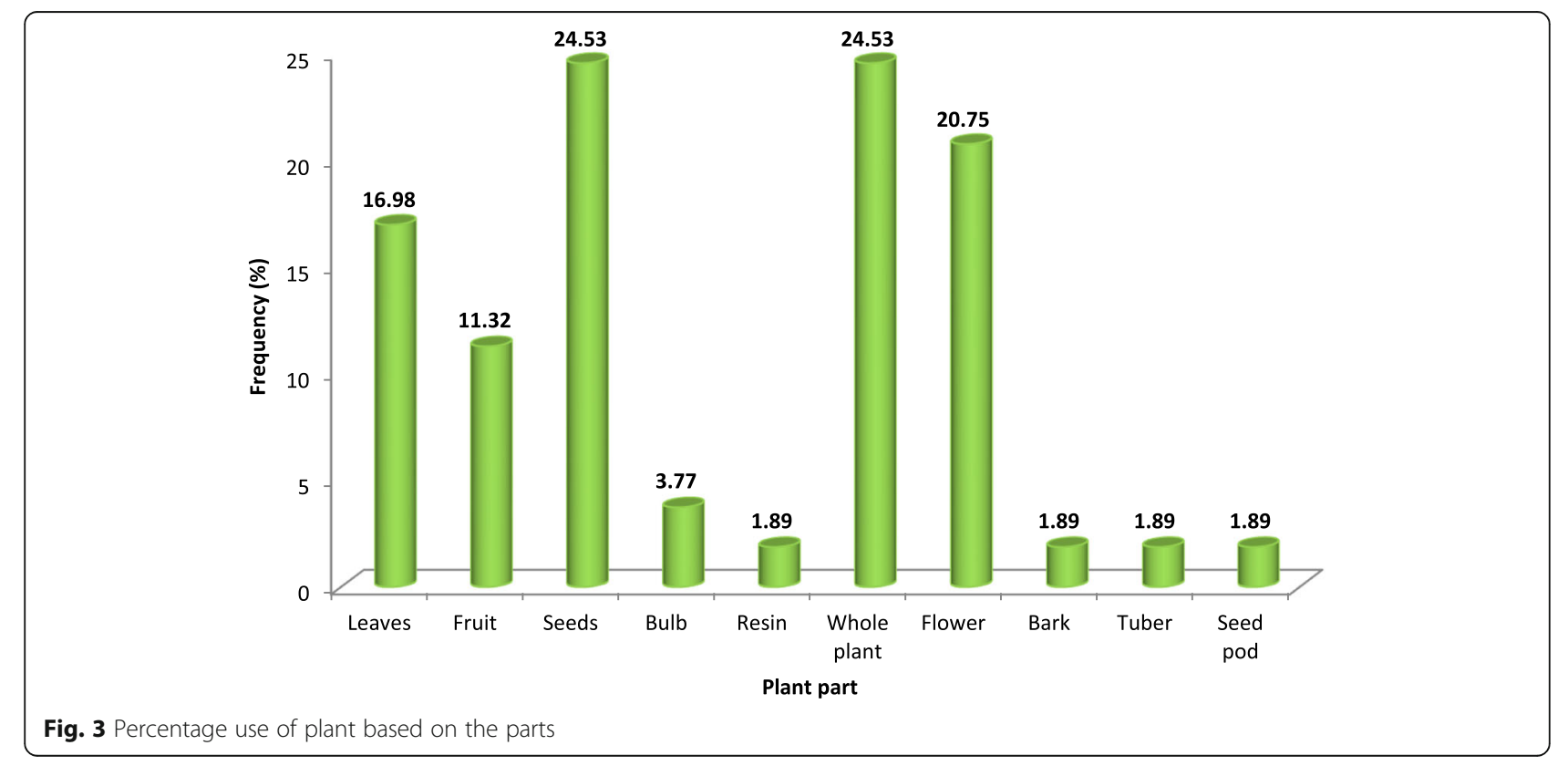




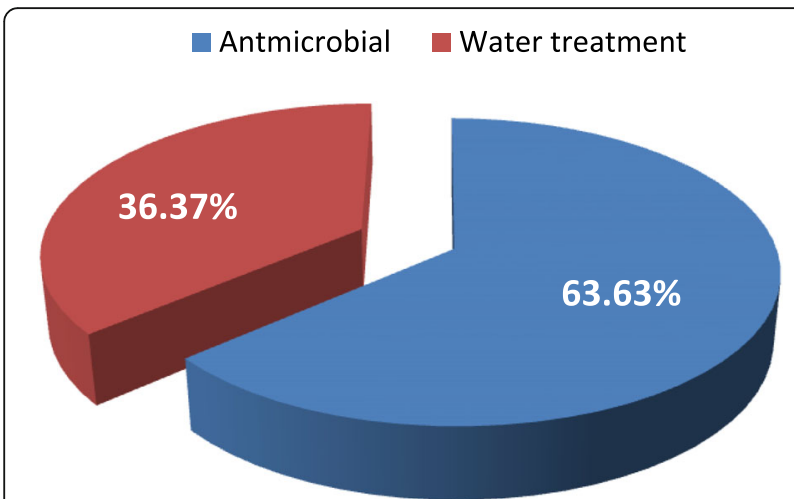

Fig. 4 Frequency (\%) of reported antimicrobial activity of plants

during the considerations of plant products. Herbal remedies can be risky to human health [210] when inappropriately used. Inappropriate combination with synthetic biocides may act to reduce the potency of conventional products. Risks may exist and be triggered by age, genetics and concurrent use of other drugs [211] for products involving plant materials. Alkaloids and cardiac glycosides have been reported for adverse effects. Some herbs with adverse effects are described by Reid et al. [212], Allard et al. [213], Maffe et al. [214], and Fatima and Nayeem [215]. Some plants previously reported in literature for adverse effects include Allium sativum, Panax ginseng, Silybam marianum, Vitis vinifera, Aloe barbadensis, Valeriana officinalis and Salix daphnoides, [210, 216-218]. Leaves of Ginkgo biloba have been reported for allergic skin reaction and seizures [210]. Chemical complexity of some plant extracts, lack of standardisation, slow working rate, poor water solubility, extraction and purification complexities are limitations that need to be overcome for industrial adoption of phytochemicals in water treatment.

\section{Conclusion and key report findings}

This review aimed at establishing emerging applications of phyto-biotics in water treatment and associated challenges in comabating multidrug resistant organism in water disinfection. It has been established that plantderived compounds are environmentally friendly, usually less toxic and have a broad medicinal application. These plant products are generally widespread, affordable, and have significant antimicrobial efficacy. Secondary metabolites from plants have found great usefulness against resistant microorgamisms and extracts of plants have been used in water treatment as natural coagulants and in reduction of microbial count of water borne pathogens. A major observation is that plant materials possess multifaceted components with manifold actions and capabilities in different fields; a characteristic not commonly found in synthetic counterpart. Challenges impeding progress and development of plants as useful biotechnological products, therefore beckon for attention to aid wide applications of phytobiotics. The use of phytochemicals in combination with synthetic antimicrobials as adjuvant needs a boost as this is a current problematic area. Novel investigations in the field of phytobiotics should engage modern methodologies such as proteomics, genomics, and metabolomics to screen safe herbs and isolate pure compounds in order to minimise challenges confronting phytobiotic safety and standardisation.

\section{Abbreviations}

MR: Microbial resistance; HIV 1: Human immunodeficiency virus 1; DNA: Deoxyribonucleic acid

\section{Acknowledgements}

Nil

\section{Authors' contributions}

All authors listed have significantly contributed to the development and the writing of this article. A.O.A conceptualised and developed the manuscript; M.A.A assisted in statistical analysis and arrangement of data; J.N.E, T.A.M.M and J.O.O read, corrected and improved the general output of this work. The author(s) read and approved the final manuscript.

\section{Funding}

There has been no significant financial support for this work that could have influenced its outcome.

\section{Availability of data and materials}

The content of this work is original and all ethical issues were well considered during the manuscript development.

\section{Ethics approval and consent to participate}

This research involves no use of experimental animals or human and need for ethical approval.

\section{Consent for publication}

All authors agreed to publish this work after a thorough peer review by Clinical Phytoscience Journal.

\section{Competing interests}

The authors declare that they have no competing interests.

\section{Author details}

${ }^{1}$ Department of Ecology and Resource Management, University of Venda, Private Bag X5050, Thohoyandou 0950, South Africa. ${ }^{2}$ Department of Hydrology and Water Resources, University of Venda, Private Bag X5050, Thohoyandou 0950, South Africa. ${ }^{3}$ Department of Microbiology, School of Sciences, Federal University of Technology, Akure, Nigeria. ${ }^{4}$ Nanotechnology and Water Sustainability Research Unit, University of South Africa, Private Bag X6, Roodepoort, Johannesburg 1705, South Africa. ${ }^{5}$ Office of The DVC Research Innovation Commercialisation and Internationalisation (RICl), Vaal University of Technology, Vanderbijlpark, South Africa.

Received: 26 March 2020 Accepted: 2 February 2021

Published online: 24 March 2021

\section{References}

1. VanWyk BE, Gericke N. People's plants, Pretoria: Briza Publications; 2000.

2. Singh D, Kumar TRS, Gupta VK, Chaturvedi P. Antimicrobial activity of some promising plants oils, molecules and formulations. Indian J Exp Biol. 2012;50: 714-7.

3. Raut JS, Shinde RB, Chauhan NM, Karuppayil SM. Polypropanoids of plant origin as inhibitors of biofilm formation by Candida albicans. J Microbiol Biotechnol. 2014;24:1216-25. 
4. Kumar S, Pandey AK. Antioxidant, lipo-protective and antibacterial activities of phyto-constituents present in Solanum xanthocarpum root. Int Rev Biophys Chem. 2012;3:42-7.

5. Savoia D. Plant derived antimicrobial compounds: alternative to antibiotics. Future Microbiol. 2012;7:979-90.

6. Emma NQ, Antonio RS, Marta AV. Screening antifungal activities of selected medicinal plants. J Ethnopharmacol. 2001;74:89-96.

7. Smith PR, Le-Breton A, Horsberg TE, Corsin F. Guidelines for antimicrobial use in aquaculture. In: Guardabassi, L., Jensen, L.B., Kruse, H., editors. Guide to antimicrobial use in animals. Oxford: Blackwell Publishing Ltd; 2009. p. 207-218.

8. Doughari HJ. Phytochemicals: Extraction Methods, Basic Structures and Mode of Action as Potential Chemotherapeutic Agents. 2012; https://doi. org/10.5772/26052.

9. Siriwardhana A, Wijesundara S, Karunaratne $V$. A review of studies on bioactive compounds isolated from Sri Lankan flora. J Natn Sci. Foundation Sri Lanka, 2015;43(1):11-33.

10. Bedoya LM, Sanchez-Palomino S, Abad MJ, Bermejo P, Alcami J. Anti-HIV activity of medicinal plant extract. J Ethnopharmacol. 2001;77(1):113-6.

11. Kumar UA, Manjunath C, Thaminzhmani T, Ravi KY, Brahmaiah Y, A review on immunomodulatory activity of plants. Indian J Novel Drug Deliv. 2012;4: 93-103

12. Ozcan G, Ozsolemez DO, Akman G, Khalilia W, Yetiz BT, Karagoz A Melikoglu G, Anil, S, Kultur S, Sutlupinar, N. Screening for antitumor activity of various plants extracts on HeLa and C4-I cell lines. J Buon. 2016;21(6): 1552-60.

13. Othman AS. Bactericidal efficacy of omega-3 fatty acids and esters present in Moringa oleifera and Portulaca oleracea fixed oils against oral and gastro enteric bacteria. Int J Pharm. 2017;13(1):44-53.

14. Iwu MM, Duncan AR, Okunji CO. New Antimicrobials of Plant Origin, Perspectives on new crops and new uses, J. Janick, editor. Alexandria: ASHS Press; 1999.

15. Hamayun M, Khan MA, Begum S. Marketing of medicinal plants of UtrorQ11 792 Gabral valleys swat, Pakistan. J Ethnobot Leaflets. SIUC, USA. 2003; 2005(1):44.

16. Kwang SS, Kiyohara H, Matsumoto $T$, Yamada H. Rhamnogalacturonan II dimers cross-linked by borate diesters from the leaves of Panax ginseng CA, Meyer are responsible for expression of their IL-6 production enhancing activities. Carbohydr Res. 1998;307:97-106.

17. Djafoua YM, Mouokeu RS, Tume C, Kamtchueng MO, Kuiate J. Immunomodulatory of methanol leaf extracts of Cameroonian medicinal plants. J Complement Integr Med. 2015;12(4):267-75.

18. Sharquie KE, AI-Turfi IA, Al-Salloum SM. The antibacterial activity of tea in vitro and in vivo (in patients with impetigo contagiosa). J Dermatol. 2000; 27:706-10.

19. Orafidiya LO, Agbani EO, Oyedele AO, Babalola OO, Onayemi O. Preliminary clinical tests on topical preparations of Ocimum gratissimum Linn leaf essential oil for the treatment of acne vulgaris. Clin Drug Invest. 2002;22 313-9.

20. Tizzani T, Venzke D, Ruani AP, Marques LB, Prazeres PHDM, Souza-Fagundes EM, Pizzolatti MG, Brighente IMC. Antitumor screening of crude extracts of ten medicinal plants of Polygala genus from Southern Brazil. J Appl Pharm Sci. 2017;7(10):79-83.

21. Alasmary FAS, Awaad AS, Kamal M, Alqasoumi SI, Zain ME. Antitumor activity of extract and isolated compounds from Drechslera rostrata and Eurotium tonophilum. Saudi Pharm J. 2018;26(2):279-85.

22. Giday M, Asfaw Z, Woldu Z. Ethnomedicinal study of plants used by Sheko ethnic group of Ethiopia. J Ethnopharm. 2010;132(2010):75-85.

23. Amri E, Kisangau D. Ethnomedicinal study of plants used in villages around Kimboza forest reserve in Morogoro, Tanzania. J Ethnobiol Ethnomed. 2010; 8(1):1-9.

24. Rahman AHMM, Khanan A. A taxonomic and ethno-medicinal study of species from Moraceae (Mullberry) family in Bangladesh flora. Res Plant Sci. 2013;1(3):53-7.

25. Coates AR, Halls G, Hu Y. Novel classes of antibiotics or more of the same? Br J Pharmacol. 2011;163:184-94.

26. Vedadhir AA, Rodrigues $C$, Lambert $H$. Social science research contributions to antimicrobial resistance: protocol for scoping review. Syst Rev. 2020;9:1-7.

27. VanBoeckel TP, Brower C, Gilbert M, Grenfell BT, Levin SA, Robinson TP, Teillant A, Laxminarayan R. Global trends in antimicrobial use in food animals. Proc Natl Acad Sci. 2015;112:5649-54.
28. Yahya MRZR, Ibrahim MSA, Zawawi WMAWM, Hamed UMA. Biofilm killing effect of Chromolaena odorata extracts against Pseudomonas aeruginosa. Res J Phytochem. 2014;8:64-73

29. Chandra H, Bishnoi P, Yadav A, Patni B, Mishra AP, Nautiyal AR. Antimicrobial Resistance and the Alternative Resources with Special Emphasis on PlantBased Antimicrobials-A Review. Plants. 2017;6:1-11.

30. Kirui JK, Kotut K, Okemo PO. Efficacy of aqueous plant extract in disinfecting water of different phytochemical properties. J Water Health. 2015;13(3):84852.

31. Abatneh $Y$, Sahu $O$, Yimer S. Purification of drinking water by low cost method in Ethopia. App Water Sci. 2014; 4:357-62.

32. McDonnell G, Russel AD. Antiseptics and disinfectants: Activity, action and resistance. Clin Microbiol Rev. 1999:12:147-79.

33. Russell AD. Types of antibiotics and synthetic antimicrobial agents. In: Denyer SP, Hodges NA, German SP, editors. Hugo and Russell's pharmaceutical microbiology, 7th edition. UK: Blackwell Science; 2004. p. 152-186.

34. Brooks GF, Butel JS, Morse SA. Jawetz, Melnick and Adelberg's Medical Microbiology, 23rd Edition. Singapore: McGraw Hill Companies; 2004.

35. Calderon CB, Sabundayo BP. Antimicrobial classifications: drugs for bugs. In: Schwalbe R, Steele-Moore L, Goodwin AC, editors. Antimicrobial susceptibility testing protocols. London: CRC Press, Taylor and Frances Group; 2007.

36. Etebu E, Arikekpar I. Antibiotics: Classification and mechanisms of action with emphasis on molecular perspectives. Int J Appl Microbiol Biotechnol. 2016:4:90-101

37. Esmatabadi MJD, Bozorgmehr A, Hajjari SN, Sombolestani AS, Malekshahi ZV, Sadeghizadeh M. Review of new insights into antimicrobial agents. Cell Mol Biol. 2017:63:40-8.

38. Talib WH. Anticancer and antimicrobial potential of plant-derived natural products, In: phytochemicals-bioactivities and impact on health. Rasooli I, editor. Croatia: Intech publications; 2011. p. 141-158.

39. Reichling J. Plant-Microbe Interactions and Secondary Metabolites with Antibacterial, Antifungal and Antiviral Properties. In: Wink M, editor. Annual Plant Reviews Volume 39: Functions and Biotechnology of Plant Secondary Metabolites. 2nd ed. Oxford: Wiley-Blackwell; https://doi.org/10.1002/ 9781444318876.ch4

40. Kennedy DO, Wightman EL. Herbal extracts and phytochemicals: plant secondary metabolites and the enhancement of human brain function. Adv Nutr. 2011;2:32-50.

41. Das K, Tiwari R, Shrivastava D. Techniques for evaluation of medicinal plant products as antimicrobial agent: current methods and future trends. J Med Plants Res. 2010:4:104-11.

42. Shin M, Umezawa C, Shin T. Antimicrobial compound in plants In Encyclopedia of Food Microbiology 2nd Edition. UK: Academic Press; 2014, p. 920-929.

43. Gyawali R, Ibrahim SA. Impact of plant derivatives on the growth of foodborne pathogens and the functionality of probiotics. Appl Microbiol Biotechnol. 2012:95:29-45.

44. Cowan MM. Plant Products as Antimicrobial Agents. Clin Microbiol Rev. 1999;12:564-82.

45. Ciocan ID, Bara II. Plant produce as antimicrobial agents. Genet Mol Biol. 2007;8:151-56

46. Bor T, Aljaloud SO, Gyawali R, Ibrahim SA. Antimicrobials from herbs, spices, and plants. In: Fruits, Vegetables, and Herbs; 2016. p. 551-578.

47. Pandey AK, Kumar S. Perspective on plant products as antimicrobials agents: a review. Pharmacologia. 2013;4:469-80.

48. Corradini E, Foglia P, Giansanti P, Gubbiotti R, Samperi R, Lagana A. Flavonoids: chemical properties and analytical methodologies of identification amd quantification in foods and plants. Nat Prod Res. 2011; 25(5):469-95.

49. Engels $C$, Schieber A, Gänzle MG. Inhibitory spectra and modes of antimicrobial action of gallotannins from Mango Kernels (Mangifera indica L.). Appl Environ Microbiol. 2011;7:2215-23.

50. O'Kennedy R, Thornes RD. Coumarins: biology, applications and mode of action. Chichester: Willey; 1997.

51. Riveiro ME, De Kimpe N, Moglioni A, Vázquez R, Monczor F, Shayo C, Davio C. Coumarins: Old Compounds with Novel Promising Therapeutic Perspectives. Curr Med Chem. 2010;17(1):1-14.

52. Kim SH, Lee SJ, Lee JH, Sun WS, Kim JH. Antimicrobial activity of 9-O-acyl and 9-O-alkylberberrubine derivatives. Med plants. 2002;68:277-81. 
53. Yi ZB, Yu Y, Liang YZ, Zeng B. Evaluation of the antimicrobial mode of berberine by LC/ ESI-MS combined with principal component analysis. J Pharm Biomed Anal. 2007:44:301-4.

54. Lewis K, Ausubel F. Prospects for plant-derived antibacterials. Nat. Biotechnol. 2006;24:1504-7

55. Taguri T, Tanaka T, Kouno I. Antibacterial Spectrum of Plant Polyphenols and Extracts Depending upon Hydroxyphenyl Structure. Biol Pharm Bull. 2006;29:2226-35

56. Abreu AC, McBain AJ, Simões M. Plants as sources of new antimicrobials and resistance-modifying agents. Nat Prod Rep. 2012;29:1007-21.

57. Taylor PW. Alternative natural sources for a new generation of antibacterial agents. Int J Antimicrob Agents. 2013;42:195-201.

58. Winward GP, Avery LM, Stephenson T, Jefferson B. Essential oils for the disinfection of grey water. Water Res. 2008;42:2260-2268.

59. Singh N, Singh RK, Bhunia AK. Sequential disinfection of Escherichia coli 0157:H7 inoculated alfalfa seeds before and during sprouting using aqueous chlorine dioxide, ozonated water, and thyme essential oil. LWT Food Sci Technol. 2003;36:235-243.

60. Pritchard M, Mkandawire T, Edmondson A, O'Niell JG, Kululanga G. Potential of using plant extracts for purification of shallow well water in Malawi. Phys Chemistry Earth. 2009:34:799-805.

61. Adeeyo AO, Odiyo JO, Odelade KA. Chemical profiling and antimicrobial properties of phyto-active extracts from Terminalia glaucescens stem against water microbial contaminants. Open Biotechnol J. 2018;12:1-15.

62. Adeeyo AO, Odiyo JO, Msagati TAM. Antimicrobial Potency of Selected Native African Herbs against Water Microbes. Journal of King Saud University - Science. 2020;32:2349-57.

63. Matthews RL, Templeton MR, Tripathi SK, Bhattarai K. Disinfection of Waterborne Coliform Bacteria by Neem Oil. Environ. Eng. Sci. 2009;26:1435-41.

64. Shaheed A, Templeton MR, Matthews RL, Tripathi SK, Bhattarai K. Disinfection of waterborne coliform bacteria using Luffa cylindrica fruit and seed extracts. Environ Technol. 2009;30:1435-40.

65. Schelz Z, Hohman J, Molnar J. Ethnomedicine: A Source of Complementary Therapeutics, Chattopadhyay D, editor. Research Signpost, 1st edition; 2010. p. 179-201

66. Khanam S, Afsar Z 2013, Herbal disinfectant: a review. World J Pharm Res. 2012;3:258-73

67. Kavitha D, Shilpa PN, Devaraj SN. Antibacterial and antidiarrhoeal effects of alkaloids of Holarrhenaanti dysenterica WALL. Indian J Exp Biol. 2004;42(6):589-94.

68. Tarfa FD, Obodozie OO, Mshelia E, Ibrahim K, Temple VJ. Evaluation of phytochemical and antimicrobial properties of leaf extract of Tapinanthus sessilifolius (P. Beauv) van Tiegh. Indian J Exp Biol. 2004;42(3):326-9.

69. Akinpelu DA, Onakoya TM. Antimicrobial activities of medicinal plants used in folklore remedies in south-western Africa. Afr J Biotechnol. 2006;5:1078-81.

70. Shariff MS, Sudarshana S, Umesha P, Hariprasad S. Antimicrobial activity of Rauvol fiatetraphylla and Physalis minima leaf and callus extracts. Afr J Biotechnol. 2006:5:946-50.

71. Hassawi D, Kharma A. Antimicrobial activity of medicinal plants against Candida albicans. J Biol Sci. 2006:6:104-9.

72. Manikandan T, Neelakandan T, Usha RG. Antibacterial activity of Salicornia brachiata, a halophyte. J Phytomed. 2009;1:441-3.

73. Joshi MG, Kamat DV, Kamat SD. Evaluation of herbal handwash formulation. Nat Prod Rep. 2008;7(5):413-5.

74. Joy JM, Kumar AP, Mohanalakshmi S, Prathyusha S. Formulation and evaluation of poly herbal hand wash. Int J Pharm. 2012;2:39-43.

75. Wani NS, Bhalerao AK, Ranaware VP, Zanje R. Formulation and Evaluation of Herbal Sanitizer. Int J Pharmtech Res. 2013:5(1):40-3.

76. Mundada AS, Mahajan M, Gangurde HH, Borkar VS, Gulecha VS, Khandare RA. Formulation and evaluation of polyherbal antipsoriatic cream. Pharmacol Online. 2009:2:1185-91.

77. Pandey A, Jagtap JV, Patil AA, Joshi RN, Kuchekar BS. Formulation and evaluation of anti-bacterial and anti-fungal activity of a herbal ointment containing Aloe-vera, Azadirachta indica and Curcuma longa. J Chem Pharm Res. 2010;2(3):182-6.

78. Shah C, Nayak B, Gaudani R, Patel J, Mod H. Formulation and evaluation of antimicrobial polyherbal cream. Pharma Sci Monitor. 2012;3:2715-22.

79. Rajasree PH, Vishwanad V, Cherian M, Eldhose J, Singh R. Formulation and evaluation of antiseptic polyherbal ointment. Int J Pharm Chem Biol Sci. 2012;3(10):2021-31.

80. Abdallah EM. Plants, An alternative source of antimicrobials. J Appl Pharm Sci. 2011;1:16-20.
81. Amataradjou MAR, Narayanan A, Baskaran SA, Venkitanarayanan K Antibiofilm effect of trans-cinnamaldehyde on uropathogenic Escherichia coli. J Urol. 2010;184(1):358-63.

82. Holler JG, Christensen SB, Slotved H, Rasmussen HB, GuzMan A, Oslen CE,Peterson B, Molgaard P. Novel inhibitory activity of the Staphylococcus aureus NorA efflux pump by a kaempfero Irhamnoside isolated from Persea lingue Nees. J Antimicrob Chemother. 2012:67(5):1138-44.

83. Upadhyay A, Johny AK, Amalaradjou MAR, Baskaran SA, Kim KS, Venkitanarayanan K. Plant-derived antimicrobials reduce Listeria monocytogenes virulence factors in vitro, and down-regulate expression of virulence genes. Int J Food Microbiol. 2012;157:88-94.

84. Koh CL, Sam CK, Yin WF, Tan LY, Krishnan T, Chong YM, Chan KG. Plantderived natural products as sources of anti-quorum sensing compounds. Sensors. 2013;13:6217-28.

85. Upadhyay A, Upadhyaya I, Kollanoor-Johny A, Venkitanarayanan K., Antibiofilm effect of plant derived antimicrobials on Listeria monocytogenes. Food Microbiol. 2013a;36:79-89.

86. Upadhyaya I, Upadhyay A, Kollanoor-Johny A, Darre MJ, Venkitanarayanan K. Effect of plant derived antimicrobials on Salmonella enteritidis adhesion to and invasion of primary chicken oviduct epithelial cells in vitro and virulence gene expression. Int J Mol Sci. 2013b;14:10608-25.

87. Mooyottu S, Kollanoor-Johny A, Flock G, Bouillaut L, Upadhyay A, Sonenshein AL, Venkitanarayanan K. Carvacrol and trans-cinnamaldehyde reduce Clostridium difficile toxin production and cytotoxicity in vitro. Int J Mol Sci. 2014;15:4415-30

88. Yin H, Chen C, Kollanoor-Johny A, Darre MJ, Venkitanarayanan K. Controlling Aspergillus flavus and Aspergillus parasiticus growth and aflatoxin production in poultry feed using carvacrol and trans-cinnamaldehyde. Poult Sci. 2015;94(9):2183-90.

89. Ahmad A, Viljoen AM, Chenia HY. The impact of plant volatiles on bacterial quorum sensing. Lett Appl Microbiol. 2015;60:8-19.

90. Iwalokun BA, Ogunledun A, Ogbolu DO, Bamin SB, Jimi-Omojola J. Invitro antimicrobial properties of aqueous garlic extract against multidrug resistant bacteria and Candida species from Nigeria. J. Med Food 2004;7(3):327-333

91. Ibrahim TA, Opawale BO, Oyinloye JMA. Antibacterial activity of herbal extracts against multidrug resistant strains of bacteria from clinical origin. Life Sci Leaflets. 2011;15:490-8.

92. Alabi MA, Olusola-Makinde O, Oladunmoye MK. Evaluation of phytochemical constituents and antibacterial activity of Chromolaena odorata L. leaf extracts against selected multidrug resistant bacteria isolated from wounds. South Asian J Res Microbiol. 2019;5(3):1-9.

93. Touani FK, Seukep AJ, Djeussi DE, Fankam AG, Noumedem JA, Kuete V. Antibiotic-potentiation activities of four Cameroonian dietary plants against multidrug-resistant Gram-negative bacteria expressing efflux pumps. BMC Complem Altern Med. 2014;14(1):1

94. Santiago C, Pang EL, Lim KH, Loh HS, Ting KN. Inhibition of penicillinbinding protein 2a (PBP2a) in methicillin resistant Staphylococcus aureus (MRSA) by combination of ampicillin and a bioactive fraction from Duabanga grandiflora. BMC Complem Altern Med. 2015;15(1):1.

95. Nascimento GG, Locatelli J, Freitas PC, Silva GL. Antibacterial activity of plant extracts and phytochemicals on antibiotic-resistant bacteria. Braz. J. Microbiol. 2000;31:247-56.

96. Verma S, Singh SP. Current and future status of herbal medicines. Vet World 2008; 1:347-50

97. Silva NCC, Fernandes JA. Biological properties of medicinal plants: a review of their antimicrobial activity. J Venom Anim Toxins Incl Trop Dis. 2010;16: 402-413.

98. Almagboul AZ, Bashir AK, Salih AKM, Farouk A, Khalid SA. Antimicrobial activity of certain Sudanese plants used in folkloric medicine for their antibacterial activity (in-vitro tests). J Appl Sci Res. 2011;7:235-56.

99. Upadhyay A, Upadhyaya I, Kollanoor-Johny A, Venkitanarayanan K. Combating pathogenic microorganisms using plant-derived antimicrobials: a mini review of the mechanistic basis. Biomed Res Int. 2014:761-41.

100. Srivastava J, Chandra H, Nautiyal AR, Kalra SJS. Antimicrobial resistance (AMR) and plant-derived antimicrobials (PDAms) as an alternative drug line to control infections. Biotechnol. 2014; 4: 451-460. Kirui JK, Kotut K, Okemo PO. Efficacy of aqueous plant extract in disinfecting water of different physicochemical properties. J Water and Health. 2015;13:849-52.

101. Tyagi-Richa SG, JasujaNakuleshwarDut M. Indian medicinal plants as an effective antimicrobial agent. Crit Rev. 2016;3(2):69-71. 
102. Nag M, Mukherjee PK, Biswasi R, ChandaJoydeb KA. Evaluation of antimicrobial potential of some Indian ayurvedic medicinal plants. Pharmacogn J. 2016;8(6):525-33.

103. Sobrinho ACN, Morais SM, Bezerra E, Santos F. The genus Eupatorium L. (Asteraceae): a review of their antimicrobial activity. J Med Plant Res. 2017; 11(3):43-57.

104. Ali SS, El-Zawawy NA, Al-Tohamy R, El-Sapagh S, Mustafa AM, Sun J, Lycium: A new bioactive antimicrobial and antioxidant agent to combat multi-drug/ pan-drug resistant pathogens of wound burn infections, J. Traditional Complem Med. 2019. https://doi.org/10.1016/j.jtcme.2019.01.004.

105. Moore-Neibel K, Gerber C, Patel J, Friedman M, Ravishankar S. Antimicrobial activity of lemon grass oil against Salmonella enterica on organic leafy greens. J Appl Microbiol. 2012;112:485-92

106. Thakur P, Chawla R, Narula A, Goel R, Arora R, Sharma RK. Anti-hemolytic, hemagglutination inhibition and bacterial membrane disruptive properties of selected herbal extracts attenuate virulence of Carbapenem Resistant Escherichia coli. Microb Pathogenesis. 2016;95:133-41.

107. Omeke PO, Obi JO, Orabueze NAl, Ike AC. Antibacterial activity of leaf extracts of Chromolaena odorata and effects of its combination with some conventional antibiotics on Pseudomonas aeruginosa isolated from wounds. J Appl Biol Bacteriol. 2019;7(03):36-40.

108. De Oliveira SM, Falcao-Silva VS, Siqueira-Junior JP, Costa MJ, de Melo Diniz MF. Modulation of drug resistance in Staphylococcus aureus by extract of Mango (Mangifera indica) peel. Brazillian J Pharmacog. 2011;21:190-3.

109. Otake T, Mori M, Ueba N, Sutardjo S, Kusumoto IT, Hattori M, Namba T. Screening of Indonesian plant extract for anti-human immunodeficiency virus type 1 (HIV-1) activity. Phytother. Res. 1995;9:6-10.

110. Kris-Etherton PM.; Hecker KD, Bonanome A, Coval SM, Binkoski AE, Hilpert KF, Griel AE, Etherton TD. Bioactive compounds in foods: their role in the prevention of cardiovascular disease and cancer. Am J Med. 2002;113:71S-88S

111. Manson MM. Cancer prevention - the potential for diet to modulate molecular signalling. Trends Mol Med. 2003:9:11-18.

112. Surh YJ. Cancer chemoprevention with dietary phytochemicals. Natural Reviews in Cancer. 2003:3:768-80.

113. Awad AB, Bradford PG, Editors. Nutrition and Cancer Prevention. Boca Raton: Taylor \& Francis; 2005.

114. Aggarwal BB, Shishodia S, Molecular targets of dietary agents for prevention and therapy of cancer. Biochem and Pharmacol. 2006;71:1397-1421.

115. Choi SW, Friso S. Nutrient-Gene Interactions in Cancer. Boca Raton: Taylor and Francis; 2006.

116. Francis MS, Wolf-Watz H, Forsberg A. Regulation of type III secretion systems. Curr Opin Microbiol. 2002;5(2):166-172

117. Andreadi CK, Howells LM, Atherfold PA, Manson MM. Involvement of Nrf2, p38, B-Raf, and nuclear factor-kappaB, but not phosphatidylinositol 3-kinase, in induction of hemeoxygenase-1 by dietary polyphenols. Mol Pharmacol. 2006;69:1033-1040.

118. Surh $Y$, Kundu JK, Na H, Lee J. Redox-sensitive transcription factors as prime targets for chemoprevention with anti-inflammatory and antioxidative phytochemicals. J Nutr. 2005;13(12):2993S-3001S.

119. Burt S. Essential oils: their antibacterial properties and potential applications in foods - a review, Int J Food Microbiol. 2004;94:223-53.

120. Upadhyay A, Karumathil DP, Upadhyaya I, Bhattaram V, Venkitanarayanan K. Controlling bacterial antibiotic resistance using plant-derived antimicrobials. In: Antibiotic Resistance; 2016. p. 205-226.

121. Falagas ME, Rafailidis PI, Matthaiou DK. Resistance to polymyxins: Mechanisms, frequency and treatment options. Drug Resist Updat. 2010;13:132-8.

122. Kahne D, Leimkuhler C, Lu W, Walsh C. Glycopeptide and Liनpoglycopeptide Antibiotics. Chem Rev. 2005;105:425-48.

123. Artsimovitch I, Chu C, Lynch AS, Landick R. A new class of bacterial RNA polymerase inhibitor affects nucleotide addition. Sci. 2003;302:650-4.

124. Patel U, Yan YP, Hobbs FW, Kaczmarczyk J, Slee AM, Pompliano DL. Oxazolidinones mechanism of action: inhibition of the first peptide bond formation. J Bio Chem. 2001;276:37199-205.

125. Talaro KP, Chess B. Foundations in microbiology, 8th edition. New York: McGraw Hill; 2008.

126. Koehn FE, Carter GT. The evolving role of natural products in drug discovery. Nat Rev Drug Discov. 2005;4:206-20.

127. Schmidt B, Ribnicky D, Poulev A, Logendra S, Cefalu W, Raskin I. A natural history of botanical therapeutics. Metab. 2008;57:3-9.

128. Gupta PD, Daswani PG, Birdi TJ. Approaches in fostering quality parameters for medicinal botanicals in the Indian context. Indian J Pharmacol. 2014;46:363-71.
129. Nazzaro F, Fratianni F, Martino L, Coppola R, Feo V. Effect of essential oils on pathogenic bacteria. Pharm. 2013;6(12):1451-74.

130. Radulovic NS, Blagojevic PD, Stojanovic-Radic ZZ, Stojanovic NM. Antimicrobial plant metabolites: structural diversity and mechanism of action. Curr Med Chem. 2013;20:932-52.

131. Chitemerere, TA, Mukanganyama S. Evaluation of cell membrane integrity as a potential antimicrobial target for plant products. BMC Complement Altern Med. 2014;14:278

132. Anandhi D, Srinivasan PT, Kumar G, Jagatheesh S. DNA fragmentation induced by the glycosides and flavonoids from C. coriaria. Int J Curr Microbiol Appl Sci. 2014;3(12):666-73.

133. Mogosanu GD, Grumezescu AM, Huang KS, Bejenaru LE, Bejenaru C. Prevention of microbial communities: novel approaches based natural products. Curr Pharm Biotechnol. 2015;16(2):94-111.

134. Brijesh S, Daswani PG, Tetali P, Antia NH, Birdi TJ. Studies on the antidiarrhoeal activity of Aegle marmelos unripe fruit. BMC Complement Altern Med. 2009:9:47.

135. Thakkar K, Parmar V, Patel D, Meshram D. Recent advances in herbal drug standardization - A review. Int J Adv Pharm Res. 2013;4:2130-8.

136. Patra KC, Pareta SK, Harwansh RK, Jayaram KK. Traditional approaches towards standardization of herbal medicines -A review. J Pharm Sci Technol. 2010;2:372-9.

137. Ahmad I, Aqil F, Owais M. Turning medicinal plants into drugs. Modern Phytomed. 2006;384:67-72

138. Xie PS, Chen SB, Liang YZ, Wang XH, Tian RT, Roy U. Chromatographic fingerprint analysis - a rational approach for quality assessment of traditional Chinese herbal medicine. J Chromatogr A. 2006:1112:171-80.

139. Liang YZ, Xie P, Chan KJ. Quality control of herbal medicines. J chromatogr B. $2004 ; 812: 53-70$

140. Soni K, Naved T. HPTLC - Its applications in herbal drug industry. Pharma Rev. 2010;112-7.

141. Nyiredy S. Progress inforced flow planar chromatography. J Chromatogr A 2003;1000:985-99.

142. Patil PS, Rajani S. An advancement of analytical techniques in herbal research. J Adv Sci Res. 2010;1:8-14

143. Shulammithi R, Sharanya M, Tejaswini R, Kwanmai M. Standardization and quality evaluation of herbal drugs. J Pharm Biol Sci. 2016;11:89-100.

144. Mihalov JJ, Marderosian AD, Pierce JC. DNA identification of commercial ginseng sample. J Agric Food Chem. 2000;48: 3744-52.

145. Shikha S, Mishra N. Genetic markers - a cutting-edge technology in herbal drug research. J Chem Pharm Res. 2009;1:1-18.

146. Gil MI,Gómez-López VM,Hung Y, Allende A. Potential of Electrolyzed Water as an Alternative Disinfectant Agent in the Fresh-Cut Industry. Food Bioprocess Technol. 2015;8:1336-48.

147. Somani SB, Ingole NW, Kulkarni NS. Disinfection of water by using sodium chloride (NaCl) and sodiumhypochlorite (NaOCl). J Eng Res Stud. 2011;2:40-3.

148. Anastasakis K, Kalderis D, Diamadopoulus E. Flocculation behavior of mallow and okra mucilage in treating wastewater. Desalination. 2009;249(2):786-91.

149. Bouaouine O, Khalil BF, Khalil F, Baudu M. Identification of functional groups of Opuntia ficus-indica involved in coagulation process after its active part extraction. Environ Sci Poll Res. 2018;25(1):11111-9.

150. Beltrán-Heredia J, Sánchez-Martin J. Removing heavy metals from polluted surface water with a tannin-based flocculant agent. J Hazard Mater. 2009; 165:1215-8

151. Özacar $M$, Sengil 'IA. Evaluation of tannin biopolymer as a coagulant aid for coagulation of colloidal particles. Colloids Surf. A: Physicochem. Eng. Aspects. 2003:229:85-96.

152. Roussy J, Chastellan P, Vooren MV, Guibal E. Treatment of ink-containing wastewater by coagulation/flocculation using biopolymers. Water SA. 2005; 31:369-76.

153. Mishra A, Bajpai M. Flocculation behaviour of model textile wastewater treated with a food grade polysaccharide. J Hazard Mater. 2005;118:213-7.

154. Al-Hamadani YAJ, Yusoff MS, Umar M, Bashir MJK, Adlan MN. Application of psyllium husk as coagulant and coagulant aid in semi-aerobic landfill leachate treatment. J Hazard Mater. 2011;190: 582-7.

155. Agarwal M, Srinivasan R, Mishra A. Study on flocculation efficiency of okra gum in sewage waste water. Macromol Mater Eng. 2001;286:560-3.

156. Suopajarvi T, Koivuranta E, Liimatainen $\mathrm{H}$, Niinimaki J. Flocculation of municipal wastewater with anionic nanocelluloses: Influence of nanocellulose characteristics on floc morphology and strength. Environ Chem Eng. 2014;2(4):2005-12. 
157. Wang J, Dang M, Duan C, Zhao W, Wang K. Carboxymethylated cellulose fibers as low-cost and renewable adsorbent materials. Ind Eng Chem Res. 2017;56(51):14940-8.

158. Beltran-Heredia J, Sanchez-Martin. Municipal wastewater treatment by modified tannin flocculant agent. Desalination. 2009;249(1):353-8.

159. Sanchez-Martin J, Gonzalez-Velasco M, Beltran-Heredia J. Surface water treatment with tannin-based coagulants from Quebracho (Schinposis balansae). Chem Eng J. 2010;165(3):851-8.

160. Heinrich M, Robles M, West JE, Montellano BRO, Rodriguez E. Ethnopharmacology of Mexican Asteracae (Compositae). Annu Rev Pharmacol. 1998:38(1):539-65.

161. Thomas E, Vandebroek I, Sanca S, Damme PV. Cultural significance of medicinal plants families and species among Quenchua farmers in Apillapampa, Bolivia. J Ethnopharm. 2009;122:60-7.

162. Rahman AHMM. An ethnobotanical investigation on Asteracae family at Rajshahi, Bangladash. Academia J. Med Plants. 2013;1(5):92-100.

163. Funk VA, Susanna A, Steussy TF, Robinson HE. Classification of Compositae systematics, evolution and biogeography of composiate. 2009.

164. Lawal IO, Uzokwe NE, Igboanugo ABI, Adio AF, Awosan EA, Nwogwugwu $\mathrm{JO}$, Faloye B, Olatunji BP, Adesaga AA. Ethnomedicinal information on collation and identification of some medicinal plants in research institutes of South West Nigeria. Afr J Pharm Pharmacol. 2010;4(1):001-7.

165. Shams-Ghahfarokhi M, Shokoohamiri MR, Amirrajab N, Moghadasi B, Ghajari A, Zeini F, Sadeghi G, Razzaghi-Abyaneh M. Invitro antifungal activities of Allium cepa, Allium sativum and Ketoconazole against pathogenic yeast and dermatophytes. Fitoterapia. 2006;77(4):321-3.

166. Athiban PP, Borthakur BJ, Ganesan S, Swathika B. Evaluation of antimicrobial efficacy of Aloe vera and its effectiveness in decontaminating gutta percha cones. J Conserv Dent. 2012;15(3):246-8.

167. Singanboina K, Chinna V, Ratnampally SK, Rao KK. Antibacterial activity of Cassia angustifolia (vahl.) leaf extracts grown in three different soil treatment. Int J Pharm Life Sci. 2014;5(6):3631-3.

168. Varsha S, Agrawal RC, Sonam P. Phytochemical screening and determination of anti-bacterial and anti-oxidant potential of Glycyrrhiza glabra extracts. J Environ Res Develop. 2013;7(4A):1552-8.

169. Habbal OA, Al-Jabri AA, El-Hag AH, Al-Mahroogi ZH, Al-Hashmi NA. In-vitro antimicrobial activity of Lawsonia inermis Linn (Henna). A pilot study on the Omani Henna. Saudi Med J. 2005;26(1):69-72.

170. Wang L, Huang Y, Yin G, Wang J, Wang P, Chen ZY, Wang T, Ren G. Antimicrobial activities of Asian Ginseng, American Ginseng and Notoginseng. Phytother Res. 2019;2019:1-11.

171. Kadota S, Basnet P, Ishii E, Tamura T, Namba T. Antibacterial activity of Trichorabdal A from Rabdosia Trichocarpa against Helicobacter pylori. Zentralbl Bakteriol. 1997;286(1):63-7.

172. Wegiera M, Kosikowska U, Malm A, Smolarz HD. Antimicrobial activity of the extracts from fruit of Rumex L. species. Central Eupr. J Biol. 2011;6:1036-1043

173. Salah-Fatnassi KBH, Hassayoun F, Cheraif I, Khan S, Jannet HB, Hammami M, Aouni M, Harzallah-Skhiri F. Chemical composition, antibacterial and antifungal, activities of flowerhead and root essential oils of Santolina chamaecyparissus L., growing wild in Tunisia. Saudi J Biol Sci. 2017;24(4): 875-82.

174. Liang Y, Duan H, Zhang P, Han H, Gao F, Li Y, Xu Z. Extraction and isolation of the active ingredients of dandelion and its antifungal activity against Candida albicans. Mol Med Rep. 2020;21(1):229-39.

175. Rezatofighi SE, Seydabadi A, Nejad SMS. Evaluating the efficacy of Achillea millefolium and Thymus vulgaris extract against Newcastle disease virus In Ovo. Jundishpur J Microbiol. 2014;7(2):e9016.

176. Izzo A, Di-Carlo G, Biscardi D, De-Fusco R, Mascolo N, Borrelli F, Capasso F, Fasulo P, Autore G. Biological screening of Italian medicinal plants for antibacterial activity. Phytother Res. 1995;9(4):281-6.

177. Benkeblia N. Antimicrobial activity of essential oil extracts of various onions (Allium cepa) and garlic (Allium sativum). LWT Food Sci Tech. 2004;37(2): 263-8.

178. Didry N, Dubreuil L, Pinkas M. Microbiological properties of proteanemonin isolated from Ranunculus bulbosus. Phytother Res. 1993;7(1):21-4.

179. Jana S, Shekhawat GS. Phytochemical analysis and bacterial screening of in vivo and in vitro extracts of Indian medicinal herb: Anethum graveolens. Res J Med Plant. 2010;4(4):206-12

180. Petrosyan MT, Sahakyan NZ, Trchounian AH. Chemical composition and antimicrobial potential of essential oil of Artemisia dracunculus L. cultivated at high altitude Armenian landscape. Chem Biol. 2018;52(2):116-21.
181. Delelegn A, Sahile S, Husen A. Water purification and antibacterial efficacy of Moringa oleifera Lam. Agric. Food Secur. 2018;7(25):1-10.

182. Shasheed A, Templeton MR, Matthews RL, Tripathi SK, Bhattarai K. Disinfection of waterborne coliform bacteria using Luffa cylindrica fruit and seeds extracts. Environ Technol. 2009;30(13):1435-40.

183. Alam MW, Pandey P, Khan F, Souayeh B, Farhan M. Study to investigate the potential of combined extracts of leaves and seeds of Moringa oleifera in ground water purification. Int J Environ Res Public Health. 2020;17(7468):1-13.

184. Villinski J, Dumas E, Chai H, Pezzuto J, Angerhofer C, Gafner S. Antibacterial activity and alkaloid content of Berberis vulgaris and Hydrastis canandensis. Pharm Biol. 2003:41(8):551-7.

185. Hamad MN, Mohammed HJ, Merdaw MA. Antibacterial activity of Calendula officianlis flowers in vitro. Ibn Al-Haitham J Pure Appl Sci. 2011:24(3):1-7.

186. Anita P, Sivasamy S, Kumar PDM, Balan IN, Ethiraj S. In vitro antibacterial activity of Camelia sinensis extract against cariogenic microorganisms. J Basic Clin Pharm. 2014;6(1):35.

187. Sokmen A, Jones BM, Erturk M. Antimicrobial activity of extracts from cell cultures of some Turkish medicinal plants. Phytother Res. 1999;13(4):355-7.

188. Careaga M, Fernandez E, Dorantes L, Mota L, Jaramilo ME, HernandezSanchez H. Antibacterial activity of Capsicum extract against Salmonella typhimurium and Pseudomonas aeruginosa inoculated in raw beef meat. Int J Food Microbiol. 2003;83(3):331-5.

189. Alkahail AA. Antifungal activity of some extract against some plant pathogenic fungi. Pak J Biol Sci. 2005;8(3):413-7.

190. Velazquez-Nunez MJ, Avila-Sosa R, Palou E, Lopez-Malo A. Antifungal activity of orange (Citrus sinensis var Valencia) peel essential oil applied by direct or vapor contact. Food Control. 2013;31(1):1-4.

191. Darughe F, Barzegar M, Sahari MA. Antioxidant and antifungal activity of Coriander (Coriandum sativum L.) essential oil cake. Int Food Res J. 2012; 19(3):1253-60

192. Cermelli C, Fabio A, Fabio G, Quaglio P. Effect of eucalyptus essential oil on respiratory bacteria and viruses. Curr Microbiol. 2008:56(1):89-92.

193. Abram V, Ulrih NP. A comparison of antioxidant and antimicrobial activity between hop leaves and hop cones. Ind. Crops and Products. 2015;64:124-34

194. Scazzocchio F, Cometa MF, Tomassini L, Palmery M. Antibacterial activity of Hydrastis canadensis extract and its major isolated alkaloids. Planta Medica. 2001:67(06):561-4

195. Kovalenko NA, Ahramovich TI, Supichenko GN, Sachivko TV, Bosak VN. Antibacterial activity of Hyssopus officinalis essential oils. Chem Plant Raw Mat. 2019;191-9.

196. Da Silveira SM, Luciano FB, Fronza N, Cunha A, Scheuermann GN, Vieira CRW. Chemical composition and antibacterial activity of Laurus nobilis essential oil towards foodborne pathogen and its application in fresh Tuscan sausage stored at 7 oC. LWT Food Sci Tech. 2014;59(1):86-93.

197. Stojiljkovic D, Arsic I, Tadic V. Extracts of wild apple fruit (Malus sylvestris (L.) Mill., Rosaceae) as a source of antioxidant substances for use in production of neutraceuticals and cosmeceuticals. Ind Crops and Products. 2016:80:165-76.

198. Allahverdiyev AM, Bagirova M, Yaman S, Koc RC, Abamor ES, Ates SC, Bayda SY, Elcicek S, Oztel ON. Development of new antiherpetic drugs based on plant compounds. In: Fighting multidrug resistance with herbal extracts, essential oils and their components. 2013; pp. 245-259.

199. Allahverdiyev A, Duran N, Ozguven M, Koltas S. Antiviral activity of the volatile oils of Melissa officinalis L. against Herpes simplex virus type 2 Phytomed. 2004;11(7-8):657-61.

200. Shahverdi AR, Monsef-Esfahani HR, Nickavar B, Bitarafan L, Khodaee S, Khoshakhlagh N. Antimicrobial activity and main chemical composition of two smokes condensates from Pehanum harmala seeds. Zeitschrift fur Naturforschung C. 2005;60(9-10):707-10.

201. Sanchez-Maldonado AF, Schieber A, Ganzle MG. Antifungal activity of secondary plant metabolite from potatoes (Solanum tuberosum L.): Glycoalkaloids and Phenolic acids synergistic effects. J App Microbiol. 2016;120(4):955-65.

202. Rezatofighi SE, Seydabadi A, Nejad SMS. Evaluating the efficacy of Achillea millefolium and Thymus vulgaris extracts against Newcastle disease virus Ovo. Jundishapur J Microbiol. 2014;7(2):e9016.

203. Kacaniova M, Heba L, Petrova J, Felsociova S, Pavelkova A, Rovna K, Bobkova A, Cubon J. Antimicrobial activity of Tussilago farfara L. J Microbio Biotech Food Sci. 2019;(2019):1343-50.

204. Hoda H, Elmi F, Elmi MM. Electrophoretic pattern and antibacterial activity of proteins from Vicia faba seed extract. 2013;2(1):46. 
205. Ozioma EOJ, Chinwe OAN. Herbal medicines in African Tradition medicine. 2019. https://doi.org/10.5772//ntechopen.80348.

206. Ullah M, Khan MU, Mahmood A, Malik RN, Hussain M, Wazir SM, Daud M, Shinwari ZK. An ethnobotanical survey of indigenous medicinal plants in Wana district South, Waziristan agency, Pakistan. J Ethnopharm. 2013;150(3): 918-24.

207. Ghimire SK, Gimenez O, Pradel R, Mckey D, Aumeeruddy-Thomas, Y. Demographic varaition and population vaibility ina threatened Himalayan medicinal and aromatic herb Nardostachys grandiflora: matrix modelling of harvesting effects in two contrasting habitats. J Appl Ecol. 2008;45:41-51.

208. Lin M, Zhang J, Chen X. Bioactive flavonoids in Moringa oleifera and their health-promoting properties. J Funct Foods. 2018;47:469-79.

209. Pandey VN, Chauhan V, Pandey VS, Upadhyaya PP, Kopp OR. A biofunctional edible plant from India, phytochemistry and medicinal properties. J Plant Stud. 2019:8

210. De Smet, PAGM. Health risks of herbal remedies: An update.Clin. Pharm. Ther. 2004;76(1):1-17.

211. Wang J, Dang M, Duan C, Zhao W, Wang K. Carboxymethylated cellulose fibers as low-cost and renewable adsorbent materials. Ind Eng Chem Res. 2017:56(51):14940-8.

212. Reid KA, Maes J, Maes A, van Staden J, De Kimpe N, Mulholland DA, Verschaeve L. Evaluation of the mutagenic and antimutagenic effects ofSouth African plants. J Ethnopharm. 2016;106(2006):44-50.

213. Allard T, Wenner T, Greten HJ, Efferth T. Mechanisms of herb-induced nephrotoxicity. CurrMed Chem. 2013;20(22):2812-9.

214. Maffè S, Paffoni P, Laura Colombo M, Davanzo F, Dellavesa P, Cucchi L, Zenone F, PainoAM, Franchetti Pardo N, Bergamasco L, Signorotti F, Parravicini U. Herbs

215. Fatima N, Nayeem N. Toxic effects as a result of herbal medicine in take. In: Solaneski S, Larramendy ML, editors. Toxicology-new aspects to this scientific conundrum. London: IntechOpen; 2016. p. 193-204.

216. Willey LB, Mady SP, Cobaugh DJ, Wax PM. Valerian overdose: a case report. VetHum Toxicol. 1995;37(4):364-5.

217. Wei L, Chen B, Ye R, Li H. Treatment of complications due to peritonealdialysis for chronic renal failure with traditional Chinese medicine. J TraditChin Med. 1999;19:3-9.

218. Schmid B, Kotter I, Heide L. Pharmacokinetics of salicin after oral administrationof a standardised willow bark extract. Eur J Clin Pharmacol. 2001;57:387-91.

\section{Publisher's Note}

Springer Nature remains neutral with regard to jurisdictional claims in published maps and institutional affiliations.

\section{Submit your manuscript to a SpringerOpen ${ }^{\circ}$ journal and benefit from:}

- Convenient online submission

- Rigorous peer review

- Open access: articles freely available online

High visibility within the field

- Retaining the copyright to your article

Submit your next manuscript at $\boldsymbol{\nabla}$ springeropen.com 